\title{
Growth Performance of Black Soldier Fly Larvae (Hermetia illucens) Fed on Some Plant Based Organic Wastes
}

\author{
Ida Kinasih', Ramadhani Eka Putra ${ }^{2 *}$, Agus Dana Permana², Finsa Firlana Gusmara ${ }^{3}$, Muhammad Yusuf Nurhadi ${ }^{3}$, \\ Ramadini Aini Anitasari ${ }^{3}$ \\ 'Department of Biology, Facullty of Sciences and Technology, Universitas Islam Negeri Sunan Gunung Djati, Bandung, Indonesia \\ ${ }^{2}$ Agricultural Engineering Study Program, School of Life Sciences and Technology, Institut Teknologi Bandung, Jatinangor Campus, \\ Bandung, Indonesia \\ ${ }^{3}$ Biology Study Program, School of Life Sciences and Technology, InstitutTeknologi Bandung, Ganesha Campus, Bandung, Indonesia
}

ARTICLE INFO

Article history:

Received February 10, 2017

Received in revised form December 15, 2017

Accepted January 17, 2018

\section{KEYWORDS:}

Bioconversion,

growth,

Hermetia illucens,

plant based organic wastes

\begin{abstract}
Insect larvae, such as black soldier fly larvae (BSFL: Hermetia illucens) are currently being considered as an alternative source of protein for poultry and aquaculture industry while in the same time apply as agent to manage organic wastes. In order to achieve both roles it is necessary to develop an appropriate farming methodology and understand the impact of different feeding source for the insect production. The study explored the effect of three local plant based organic wastes as feedstocks to growth of the black soldier fly larvae. Separate feeding trials on horse manure (HM), vegetable wastes (VW), and tofu dreg (TD) was done and their effect on BSF larvae growth rate, larvae weight and total prepupal yield in grams content analysed. The efficiency of the BSF larvae to consume and ability to reduce the waste load of the different substrates was also evaluated. The result showed all materials suitable as feeding material for black soldier fly. Difference on physical properties and chemical content affected the development time, harvested biomass, efficiency of digestivity, and efficiency of biomass production which is unique for each type of waste. This study provide base line information for future development of plant based organic waste management.
\end{abstract}

\section{Introduction}

For decades, researchers worldwide have developed an alternative method to manage organic wastes through decomposition by macrofauna such as black soldier fly larva (BSFL), earthworm, house fly, and mealworm (Beard and Sands 1973; El Boushy 1991; Ndegwa and Thompson 2001; Ramos-Elorduy et al. 2002; Elissen et al. 2006; Diener et al. 2009), in which black soldier fly considered as the best candidate.The black soldier fly is native species of neotropic and now found worldwide through humanmediated dispersal and natural dispersal (Callan 1974; Marshall et al. 2015). Studies showed that larva of this species has the ability to consume wide range of organic wastes such as agricultural wastes (Manurung et al. 2016; Supriyatna et al. 2016), animal and human remains (Tomberin et al. 2005; Pujol-Liz et al. 2008), fish offal (St-Hilaire et al. 2007a), food waste (Diener et al. 2011; Nguyen et al. 2013; Oonincx et al. 2015a), as well human and livestock feces (Fatchurochim et al. 1989; Myers et al. 2008; Banks et al. 2014; Oonincx et al. 2015b). Due to this ability and the

* Corresponding Author.

E-mail Address: ramadhani@sith.itb.ac.id fact that the species also able to be mass-produced (Sheppard et al. 2002), this species has been studied as decomposer that recycling nutrients in organic wastes into their biomass which is high in protein and fat, a process called bioconversion (Sheppard et al. 1994; Diener et al. 2009; Li et al. 2011; Surendra et al. 2016). The biomass of the larvae is applicable as part of ingredient of feed for aquaculture, livestock, and poultry industries (Newton et al. 1977; St-Hilaire et al. 2007b; Hariadi et al. 2014; Li et al. 2016; Magalhaes et al. 2017; Renna et al. 2017; Schiavone et al. 2017) even as potential source for biodiesel (Zheng 2012).

In Indonesia, large numbers of various types of organic wastes produced by local small to large scale agroindustry, tourism, and household. Each of them has unique nature and properties. Restaurant waste, for example, containing parts of animal and plant which rich in carbohydrate and relatively similar amount of protein and fat while on the other hand fruits and vegetables rich in carbohydrate with significantly low-fat content. Studies showed that each type of diet would affect the development, productivity, some life history traits, and chemical composition of the biomass (Tomberlin et al. 2002; Oonincx et al. 2015a; Tschirner and Simon 2015; Cammack and Tomberlin 2017). Among organic wastes produces in Indonesia, 
plant-based wastes are considered the most dominant and produced by various human activities.

This study was designed to imitate the real condition in Indonesia in term of variation of plantbased organic wastes produced. The objectives of this experiment were 1) to determine the effects of diet composition on growth, development time, and prepupal weigth and 2) to compare the consumption efficiency when larva fed with different types of waste materials. The results of this study could be applied as guideline to design optimum and sustain integration system between plant-based organic wastes bionconversion system to activities that produced the wastes.

\section{Materials and Methods}

\subsection{Animal Specimen}

Larvae of the black soldier fly (in this manuscript will be state as BSFL) were obtained from eggs purchased from commercial BSF farms in Sumedang and Depok (both areas are in West Java) in order to augmented egg produced by black soldier fly colonies kept in Laboratory of Environmental Toxicology, School of Life Sciences and Technology, Bandung, Indonesia. All eggs were kept on substance made of commercial chicken feed (60\% moisture) and kept at constant temperature $\left(28^{\circ} \mathrm{C}\right.$, $70 \% \mathrm{RH})$ in a container $(50 \mathrm{~cm} \times 25 \mathrm{~cm} \times 10 \mathrm{~cm})$ at Laboratory of Environmental Toxicology, School of Life Sciences and Technology, Bandung, Indonesia prior used.

\subsection{Waste Materials}

In this study, three types of organic wastes were tested. Those wastes were (1) vegetable wastes (VW) originated from a local traditional market in Bandung, (2) house manure (HM) from horse stall at Ecopesantren Daarut Tauhid, Paronpong, West Bandung, and (3) tofu dreg (TD) from local tofu maker in Sumbersari, Bandung.

Prior application, all wastes kept in closed plastic bags and stored in the refrigerator with temperature $-5^{\circ} \mathrm{C}$ to prevent decaying by microorganism activities.

\subsection{Feed Rates}

Each treatment (three replicates for each treatment) contained 200 of six days old larva (hand counted). Larvae fed with five different daily food rates: $12.5,25,50,100$, and $200 \mathrm{mg} /$ larvae/day (wet weight) for each wastes material.

The larvae were initially placed onto the prepared food within plastic cup (height $12 \mathrm{~cm}$, upper diameter $7 \mathrm{~cm}$, lower diameter $5 \mathrm{~cm}$ ) and covered with a black plastic sheet to protect them from light disturbance. Dark cloth (diameter $0.01 \mathrm{~mm}$ ) was clamped between box and lid to prevent infestation of feeding materials by other flies and parasitoid attacks. Twenty four hours prior used, food rations were prepared, weighed, and kept frozen.
Data collection and feeding were performed every three days. At the same time, the larvae were transferred into another glass already filled with next feed. The residual material of previous glass was dried at $60^{\circ} \mathrm{C}$ for dry mass determine.

Feeding of larvae was continued until more than $40 \%$ of all larvae metamorphosed into prepupal (Tomberlin et al. 2002) while weighing of larvae continued until each larvae metamorphosed into prepupae. All prepupal were removed daily from each container and weighed, then placed in a plastic container for further rearing process into adults. Prepupal and pupal were held in the same incubator in which the larvae were reared and were monitored for adult emergence daily (Cammack and Tomberlin 2017).

\subsection{Digestibility}

Ability of larvae to digest wastes used in this study was determined by calculating Efficiency of Digested Feed (ECD) based on terminology of Scriber and Slansky (1981).

$\mathrm{B}=(\mathrm{I}-\mathrm{F})-\mathrm{M}$

$\mathrm{ECD}=\mathrm{B} / \mathrm{I}-\mathrm{F}$

where $B=$ assimilated food used for growth (measured as prepupal biomass), $\mathrm{I}=$ total food offered during the experiment, $\mathrm{F}=$ residue in the experimental cup (undigested food + excretory products), and $\mathrm{M}$ = assimilated food metabolized (calculated by mass balance). All figures are given in mg (dry weight). Higher ECD indicates better food conversion efficiency. All collected data compared with the result of Diener et al. (2009) which considered as the most common method to produce larvae for feedstock material.

\subsection{Mass Balance}

Mass balance is an approach to design biomass production system and to predict the digestibility of diet. Based on this approach, the total number of feed consumed by larva was divided into three output, the mass of diet material that use to maintain homeostasis of larva, the mass of undigested diet material, and the harvested biomass (Figure 1).

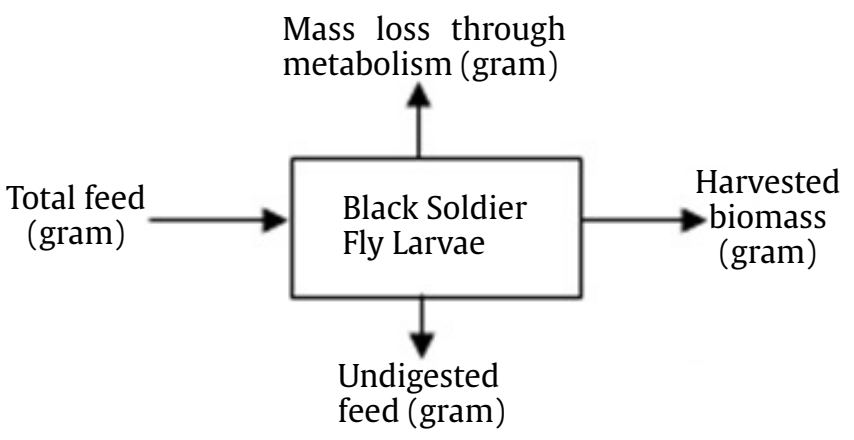

Figure 1. Mass balance model of bioconversion of organic waste into body biomass of black soldier fly larva 


\subsection{Data Analysis}

One way ANOVA $(\mathrm{P} \leq 0.05)$ with subsequent Tukey HSD tests was applied to detect difference on data collected among all treatments.

\section{Results}

\subsection{Development Time}

Larvae spent less time with increasing amount of feeding material provided to them. Larvae fed with organic wastes spent more time in development compared with the ones fed on chicken feed (except for BSFL group fed with TD at rate $12.5 \mathrm{mg} /$ larva/day).

Among organic wastes applied in this study, BSFL group fed with TD had shorter development time. However, all treatment groups have similar development time when fed with rate of $100 \mathrm{mg} /$ larvae/day and more (Figure 2).

\subsection{Prepupal Weight}

There were two groups of larvae based on the prepupal weight. Prepupal weight of HM and VW groups was similar on the trend and value for all feed rate. On the other hand, both TD and CF groups had significantly heavier prepupal than groups HM and VW (ANOVA, $\mathrm{p}<0.05$ ) (Figure 3 ).

Feeding BSFL with TD on the feed rate more than $25 \mathrm{mg} /$ larvae/day produced slightly heavier prepupal compared to other groups (ANOVA, $\mathrm{p}>0.05$ ) (Figure 3).

\subsection{Digestibility}

Vegetables waste and CF more easier to be digested and converted into energy at lower feed rate. On the other hand, efficiency of conversion increased with higher feed rate until reached a threshold when larvae fed with TD while there was stable digestibility of horse manure (Figure 4 ).

Larvae feed with TD on the feed rate of $50 \mathrm{mg} /$ larvae/day and vegetable waste on the rate of 12.5 $\mathrm{mg} /$ larvae/day showed highest conversion efficiency (48.1\% and 49.54\%, respectively) (ANOVA, $\mathrm{p}<0.05$ ).

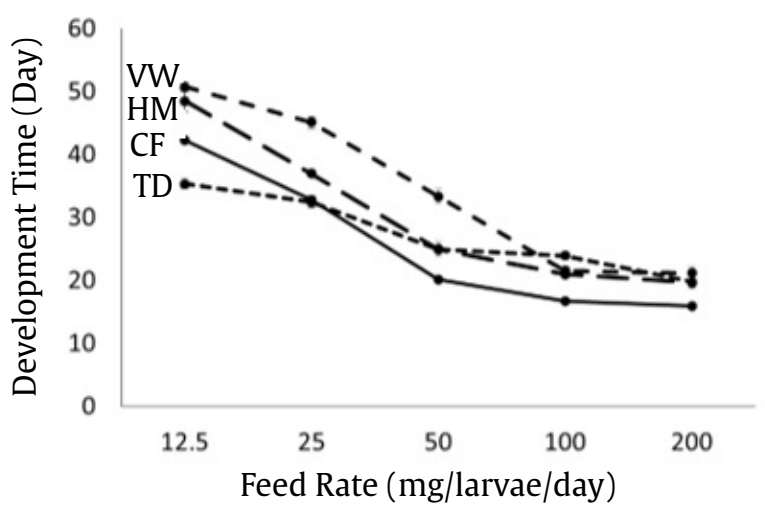

Figure 2. Developmental time of black soldier fly larvae fed on different organic wastes. TD: Tofu Dreg, VW: Vegetables Waste, HM: Horse Manure, CF: Chicken Feed (Diener 2009)

\subsection{Mass Balance}

All treatment showed different pattern of proportion of feed converted into prepupal biomass, used for metabolism, and undigested. On average, most of feed converted into residue except for VW group (Figure 5).

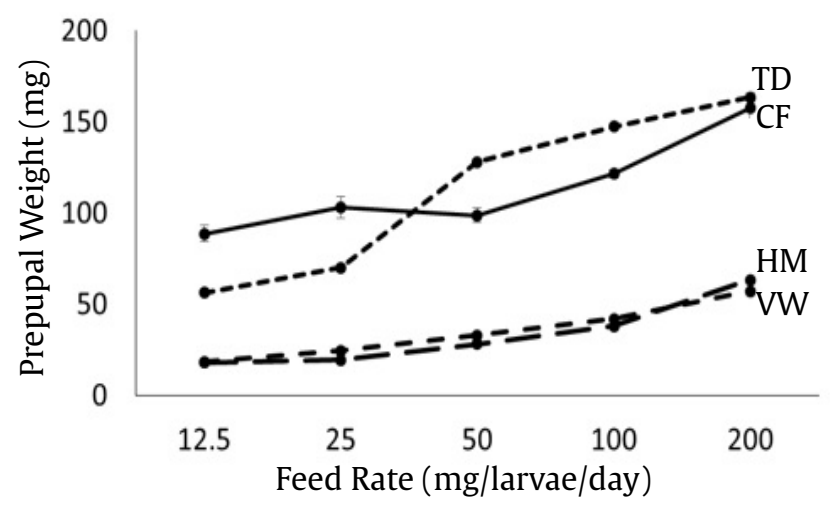

Figure 3. Prepupal weight of black soldier fly larvae fed on organic wastes. TD: Tofu Dreg, VW: Vegetables Waste, HM: Horse Manure, CF: Chicken Feed (Diener 2009)

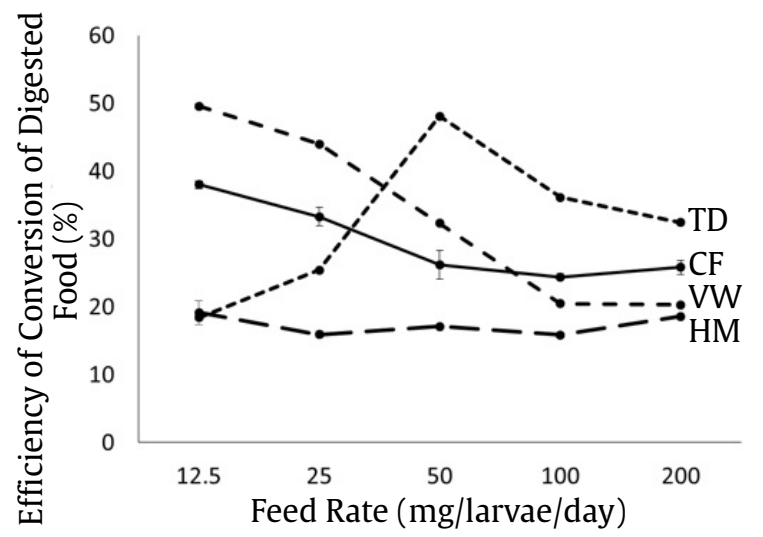

Figure 4. Efficiency of Conversion of Digested Food (ECD) of black soldier fly larvae fed on organic wastes. TD: Tofu Dreg, VW: Vegetables Waste, HM: Horse Manure, CF: Chicken Feed (Diener 2009)

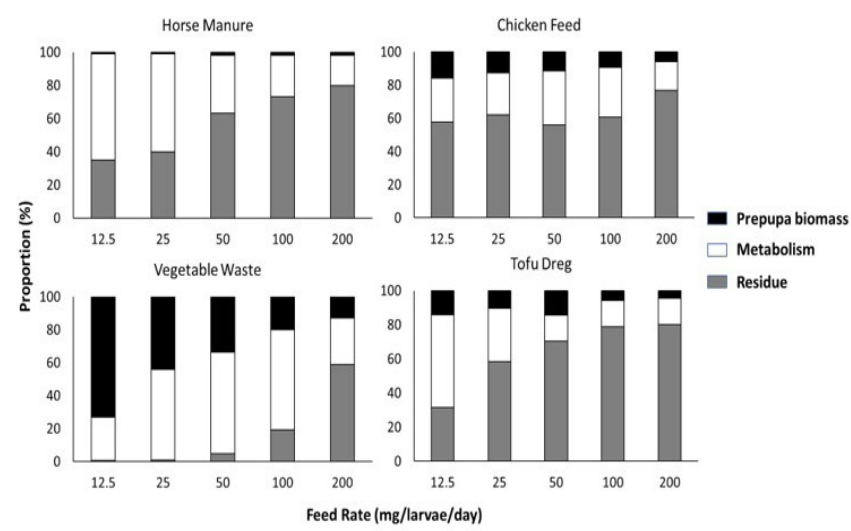

Figure 5. Proportion of feed converted into prepupal biomass, used for metabolism, and residue by black soldier fly larvae fed on organic wastes. TD: Tofu Dreg, VW: Vegetables Waste, HM: Horse Manure, CF: Chicken Feed (Diener 2009). 


\section{Discussion}

\subsection{Developmental Time}

The developmental time of BSFL in this study generally shorter than some of previous studies (Table 1). It seems BSFL able to consume and digest plant based organic wastes tested in this study as their only nutrient source.

Slower development time of the larvae fed on organic wastes could be related to the quality of the food especially balance in nutritional contents. Unlike chicken feedstock which designed with all nutritional content for growth, all organic wastes characterized with the abundance of particular nutrition while lacking in others. Nutritional imbalance in diet could lead to an increase in consumption period of insect larvae to compensate for deficient in the nutrients especially proteins and carbohydrates (Nijhout 2003; Wright et al. 2003; Lee et al. 2004; Simpson et al. 2006; Banks et al. 2014). Lack of particular nutrient influenced the time when larvae reaching a critical developmental stage (Nijhout 1981). In insect, larval weight is attained to the critical stage of development (Nijhout and Williams 1974; Blakley and Goodner 1978; Keena 2005). At this stage, a shift in hormonal level occurs that induce further development (Berreuer et al. 1979; Raubenheimer and Simpson 1997).

\subsection{Prepupa Weight}

During larvae stage, insect consumes a large quantity of food as a reserve for adult stage. The weight of larvae highly depends on the composition of food. The study by Tschriner and Simon (2015) showed the importance of protein to produce heavier larvae which explained the lighter prepupal weight of HM and WM (both are rich in complex carbohydrate) compared to CF and TD (both are rich in protein and simple carbohydrate) (Li et al. 2012).

Prepupal weight highly affects the growth, survival, and biological traits related to reproduction of adult flies (Roper et al. 1996; Blackmore and Lord 2000; Liu et al. 2008). As for black soldier fly, lower prepupal weight could hamper the sustainability of bioconversion process as they will produce adults with lower reproduction ability (Gobbi et al. 2013). The result also indicated that the development time could be reduced by applying more food to the larvae as the larvae compensate low food quality by consuming more food to obtain the required amount of specific nutrition.

\subsection{Efficiency of Conversion}

The ECD level recorded in this study was relatively higher than most of the previous studies (Table 2). The result of this study agreed with the conclusion of previous studies indicated lower ECD when BSFL consumed the low quality and/or quantity diet.
Table 1. Comparative data on development time for black soldier fly larvae on various substrates

\begin{tabular}{llc}
\hline \multicolumn{1}{c}{ Reference } & \multicolumn{1}{c}{ Substrate } & $\begin{array}{c}\text { Development } \\
\text { time (days) }\end{array}$ \\
\hline Myers et al. (2008) & Dairy manure & $28-30$ \\
Li et al. (2011) & Dairy manure & $<31$ \\
Gobbi et al. (2013) & Meat meal & 33 \\
Gobbi et al. (2013) & Hen feed & 15 \\
$\begin{array}{l}\text { Manurung et al. } \\
\text { (2016) }\end{array}$ & Rice straw & $38-52$ \\
$\begin{array}{l}\text { Supriyatna et al. } \\
\text { (2016) }\end{array}$ & Cassava peel & $20-54$ \\
\hline
\end{tabular}

Table 2. Comparative data on efficiency of conversion of digested-feed (ECD) for black soldier fly larvae on various substrates

\begin{tabular}{lll}
\hline \multicolumn{1}{c}{ Reference } & \multicolumn{1}{c}{ Substrate } & \multicolumn{1}{c}{ ECD (\%) } \\
\hline Manurung et al. (2016) & Rice straw & $5.69-10.85$ \\
Supriyatna et al. (2016) & Cassava peel & $12-21$ \\
Abduh et al. (2017) & Rubber seed & $12.5-25.9$ \\
Abduh et al. (2017) & $\begin{array}{l}\text { Pandanus } \\
\text { tectorius fruits }\end{array}$ & $6.3-27.4$ \\
\hline
\end{tabular}

\subsection{Mass Balance}

This study showed variation in proportion of feed converted into prepupal biomass, used for metabolism, and residue. In general, based on the mass balance, increasing feed rate produced more residue during bioconversion process of all material tested while the proportion for metabolism was decreased with more food.

We proposed two hypotheses to explain this pattern: (1) Under abundance food source, high amount of food also increase the amount of major organic substances (i.e protein, amino acid, lipid) for growth which is in total higher than the required amount. Under this condition there was possibility high amount of left over diet which became residue, (2) During food scarcity, larva adjusts their energy budget and prioritize energy allocation to maintain their homeostasis by increasing metabolism of consumed food and reduce excretion (Roff 2001; Glazier 2002; Hou 2014). Larvae also increase their consumption rate thus reducing the amount of residue (Couture et al. 2016). By applying this strategy larvae keep their good health which allowing them to resume growth after food scarcity is over (known as compensatory growth) (Mangel and Munch 2005; Dmitriew 2011).

On the other hand, when larvae feed with vegetable waste at low feed rate most of the food convert into biomass. This result may relate to moisture and water content of vegetables allowing larvae to use smaller energy for metabolism and concentrated to biomass. At high feed rate, mass of undigested vegetables easily loss through transpiration. Further studies are required to test this hypothesis. 


\section{Conclusion}

This study showed composition of nutrient of the organic waste affects the development of BSFL. However, providing BSFL with large amount of feed may overcame the negative effect of low quality feed to developmental time despite small pupa size and possible negative effect of reproduction.

\section{Acknowledgements}

This study was partly and equally supported by DIPA BOPTAN UIN Sunan Gunung Djati Bandung granted to first author, Riset Kompetensi granted to corresponding author, and P3MI funding granted to third author.

\section{References}

Abduh MY et al. 2017. Bioconversion of rubber seeds to produce protein and oil-rich biomass using black soldier fly larva assisted by microbes.J Entomol Zool Stud 5(4):591-597.

Abduh MY et al. 2017. Bioconversion of Pandanus tectorius using black soldier fly larvae for the production of edible oil and protein-rich biomass. J Entomol Zool Stud 5(1):803-809.

Banks IJ et al. 2014. Growth rates of black soldier fly larvae fed on fresh human faeces and their implication for improving sanitation. Trop Med Int Health 19:14-22.

Beard RL, Sands DC. 1973. Factors affecting degradation of poultry manure by flies. Environ Entomol 2: 801-806.

Berreur P et al. 1979. Ecdysone levels and pupariation in a temperature sensitive mutation of Drosophila melanogaster. J Exp Biol 210:333-373.

Blackmore MS, Lord CC. 2000. The relationship between size and fecundity in Aedes albopictus. J Vector Ecol 25: 212-217.

Blakley N, Goodner SR. 1978. Size-dependent timing of metamorphosis in milkweed bugs (Oncopeltus) \& its life history implications. Biol Bull 155: 499-510.

Callan EM 1974. Hermetia illucens (Dipt. Stratiomyidae), A cosmopolitan american species long established in Australia and New-Zealand. Entomol Mon Mag 109: 232-234.

Cammack JA, Tomberlin JK. 2017. The impact of diet protein and carbohydrate on select life-history traits of the black soldier fly Hermetia illucens (L.) (Diptera: Stratiomyidae). Insects 8: 56.

Couture JJ et al. 2016. Behavioral and morphological responses of an insect herbivore to low nutrient quality are inhibited by plant chemical defenses. Anthropod Plant Interact 10(4): 341-349.

Diener S et al. 2011. Biological treatment of municipal organic waste using black soldier fly larvae. Waste Biomass Valori 2: 357-363.

Diener S et al. 2009. Conversion of organic material by black soldier fly larvae: estabilishing optimal feeding rates. Waste Manage Res 27: 603-610.

Dmitriew CM 2011. The evolution of growth trajectories: what limits growth rate? Biol Rev 86: 97-116.

El Boushy A 1991. House fly pupae as poultry manure converters for animal feed: a review. Bioresour Technol 28: 45-49.
Elissen $\mathrm{HJH}$ et al. 2006. A new reactor concept for sludge reduction using aquatic worms. Water Res 40: 37133718.

Fatchurochim S et al. 1989. Filth fly (Diptera) oviposition and larval development in poultry manure of various moisture levels. J Entomol Sci 24: 224-231.

Glazier DS 2002. Resource-allocation rules and the heritability of traits. Evolution 56: 1696-1700.

Gobbi P et al. 2013. The effects of larval diet on adult lifehistory traits of the black soldier fly, Hermetia illucens (Diptera: Stratiomyidae). Eur J Entomol 110(3): 461468.

Hariadi S et al. 2014. Kombinasi larva lalat bunga (Hermetia illucens L.) dan pelet untuk pakan ikan patin jambal (Pangasius djambal). J Akuakultur Rawa Indonesia 2(2):150-161.

Hou C 2014. Increasing energetic cost of biosynthesis during growth makes refeeding deleterious. Am Nat 184: 233-247.

Keena MA 2005. Pourable artifcial diet for rearing Anoplophora glabripennis (Coleoptera: Cerambycidae) and methods to optimize larval survival and synchronize development. Ann Entomol Soc Am 98: 536-547.

Kim W et al. 2011. Biochemical characterization of digestive enzymes in The Black Soldier Fly, Hermetia illucens (Diptera: Stratiomyidae).J Asia Pacific Entomol 14(1): 11-14.

Lee KP et al. 2004. A comparison of nutrient regulation between solitarious and gregarious phases of the specialist caterpillar, Spodoptera exempta (Walker). J Insect Physiol 50:1171-1180.

Lee CM et al. 2014. Screening and characterization of a novel cellulase gene from the gut microflora of Hermetia illucens using metagenomic library. J Microbiol Biotechnol 24(9): 1196-1206.

Li B et al. 2012. Isolation and structural characterisation of okara polysaccharides. Molecules 17: 753-761.

Li Q, Zheng L et al. 2011. Bioconversion of dairy manure by black soldier fly (diptera: Stratiomyidae) for biodiesel and sugar production. Waste Manage 31: 1316-1320.

Li $\mathrm{S}$ et al. 2016. Influence of black soldier fly (Hermetia illucens) larvae oil on growth performance, body composition, tissue fatty acid composition and lipid deposition in juvenile Jian carp (Cyprinus carpio var. Jian). Aquaculture 465: 43-52.

Liu QL et al. 2008. Black soldier fly (Diptera: Stratiomyidae) larvae reduce Escherichia coli in dairy manure. Environ Entomol 37: 1525-1530.

Magalhaes R et al. 2017. Black soldier fly (Hermetia illucens) pre-pupae meal as a fish meal replacement in diets for European seabass (Dicentrarchus labrax). Aquaculture 476: 79-85.

Mangel M, Munch SB. 2005. A life-history perspective on short- and long-term consequences of compensatory growth. Am Nat 166: 155-176.

Manurung R et al. 2016. Bioconversion of Rice straw waste by blacksoldier fly larvae (Hermetia illucens L.): Optimal feed rate for biomass production. J Entomol Zool Stud 4(4): 1036-1041.

Marshall SA et al. 2015. The historical spread of the Black Soldier Fly, Hermetia illucens (L.) (Diptera, Stratiomyidae, Hermetiinae), and its establishment in Canada. J Entomol Soc Ontario 146: 51-54.

Myers $\mathrm{H}$ et al. 2008. Development of black soldier fly (Diptera: Stratiomyidae) larvae fed dairy manure. Environ Entomol 37: 11-15. 
Ndegwa PM, Thompson SA. 2001. Integrating composting and vermicomposting in the treatment and bioconversion of biosolids. Bioresour Technol 76: 107-112.

Newton GL et al. 1977. Dried Hermetia illucens larvae meal as a supplement for swine. J Anim Sci 44: 395-400.

Nguyen TTX et al. 2013. Influence of resources on Hermetia illucens (Diptera: Stratiomyidae) larval development. J Med Entomol 50: 898-906.

Nijhout HF, Williams CM. 1974. Control of moulting and metamorphosis in the tobacco hornworm, Manduca sexta (L.): growth of the last-instar larva and the decision to pupate. J Exp Biol 61: 481-491.

Nijhout HF 1979. Stretch-induced moulting in Oncopeltus fasciatus. J Insect Physiol 25: 277-281.

Nijhout HF 1981. Physiological control of moulting in insects. Am. Zool 21: 631-640.

Nijhout HF 2003. The control of body size in insects. Dev Biol 261:1-9.

Oonincx DGAB et al. 2015a. Feed conversion, survival and development, and composition of four insect species on diets composed of food by-products. PLOS ONE 10: e0144601.

Oonincx DGAB et al. 2015b. Nutrient utilisation by black soldier flies fed with chicken, pig, or cow manure. $J$ Insects Food Feed 1: 131-139.

Pujol-Luz JR et al. 2008. The black soldier-fly, Hermetia illucens (Diptera, Stratiomyidae), used to estimate the postmortem interval in a case in Amapa State, Brazil. J Forensic Sci 53:476-478.

Ramos-Elorduy J et al. 2002. Use of Tenebrio molitor (Coleoptera: Tenebrionidae) to recycle organic wastes and as feed for broiler chickens. J Econ Entomol 95: 214-220.

Raubenheimer D, Simpson SJ. 1997. Integrative models of nutrient balancing: application to insects and vertebrates. Nutr Res Rev 10: 151-179.

Renna M et al. 2017. Evaluation of the suitability of a partially defatted black soldier fly (Hermetia illucens L.) larvae meal as ingredient for rainbow trout (Oncorhynchus mykiss Walbaum) diets. J Anim Sci Biotechnol 8:57.

Roff DA 2001. Life history evolution, Sinauer Associates, Sunderland.

Roper C et al. 1996. Evolutionary responses of Drosophila melanogaster life history to differences in larval density. J Evol Biol 9:609-622.

Sadet-Bourgeteau S, Julliand V. 2010. Equine microbial gastro-intestinal health. The impact of Nutrition on the Health and Welfare of Horses. EAAP Publication. Amsterdam p. 161-82.

Schiavone A et al. 2017. Partial or total replacement of soybean oil by black soldier fly larvae (Hermetia illucens L.) fat in broiler diets: effect on growth performances, feed-choice, blood traits, carcass characteristics and meat quality. Italian J Anim Sci 16(1):93-100.
Scriber JM, Slansky F. 1981. The nutritional ecology of immature insects. Ann Rev Entomol 26: 183-211.

Sheng $\mathrm{T}$ et al. 2016. Lignocellulosic saccharification by a newly isolated bacterium, Ruminiclostridium thermocellum M3 and cellular cellulase activities for high ratio of glucose to cellobiose. Biotechnol Biofuels 9: 172.

Sheppard DC et al. 1994. value added manure management system using the black soldier fly. Bioresour Technol 50: $275-279$

Sheppard DC et al. 2002. Rearing methods for the black soldier fly (Diptera: Stratiomyidae). J Med Entomol 39: 695-698.

Simpson SJ et al. 2006. Cannibal crickets on a forced march for protein and salt. Proc. Natl. Acad. Sci. U.S.A. 103:4152-4156.

St-Hilaire S et al. 2007a. Fish offal recycling by the black soldier fly produces a foodstuff high in omega-3 fatty acids. J World Aquacult Soc 38: 309-313.

St-Hilaire S et al. 2007b. Fly prepupae as a feedstuff for rainbow trout, Oncorhynchus mykiss. JWorld Aquacult Soc 38(1): 59-67.

Supriyatna A et al. 2016. Growth of black soldier larvae fed on cassava peel wastes, An agriculture waste. J Entomol Zool Stud 4(6): 161-165.

Surendra KC et al. 2016. Bioconversion of organic wastes into biodiesel and animal feed via insect farming. Renew Energy 98: 197-202.

Tomberlin JK et al. 2002. Selected life-history traits of black soldier flies (Diptera: Stratiomyidae) reared on three artificial diets. Ann Entomol Soc Am 95:379-387.

Tschirner M, Simon A 2015. Influence of different growing substrates and processing on the nutrient composition of black soldier fly larvae destined for animal feed. I Insects Food Feed 1 (4):249-259.

Wright GA et al. 2003. The feeding behavior of the weevil, Exophthalmus jekelianus, with respect to the nutrients and allelochemicals in host plant leaves. Oikos 100:172-184.

Zheng L et al. 2013. A survey of bacterial diversity from successive life stages of black soldier fly (Diptera: Stratiomyidae) by using $16 \mathrm{~S}$ rDNA pyrosequencing. J Med Entomol 50: 647-658.

Zheng L et al. 2012. Double the biodiesel yield: Rearing black soldier fly larvae, Hermetia illucens, on solid residual fraction of restaurant waste after grease extraction for biodiesel production. Renew Energy 41:75-79. 